\title{
SEJARAH PERKEMBANGAN ISLAM DI ALJAZAIR
}

\author{
Syaiful Anam \\ Sekolah Tinggi Ilmu Tarbiyah Madani Yogyakarta \\ e-mail: syaiful_anam@stitmadani.ac.id
}

\begin{abstract}
Abstrak
Aljazair adalah bagian dari geografis dan ekonomi dari etnik Maghrib yang mendominasi wilayah Muslim dari Barat Libya hingga Samudera Atlantik. Orang Muslim di Aljazair bisa dibagi ke dalam dua bagian, yaitu bangsa Arab dan bangsa Berber. Penduduk asli di Aljazair adalah suku Berber. Aljazair beberapa kali dikuasai oleh bangsa asing. Hal ini disebabkan oleh keadaan penduduknya yang terbagi-bagi kedalam berbagai suku. Sebelum kedatangan Prancis, konsep pendidikan di Aljazair memberikan mata pelajaran tentang ilmu Al-Qur'an, tafsir, aritmatika dan lain-lain. Kemudian dengan dibuat kebijakan baru oleh Prancis, metode belajar dirubah dengan menggunakan bahasa dan budaya Prancis membuat sekolah-sekolah lokal terpaksa ditutup. Kondisi ini membuat sebagian besar anakanak tidak bisa melanjutkan pendidikannya, karena yang mampu untuk melanjutkan pendidikannya hanya keluarga daru kalangan atas saja. Ditambah lagi dengan datangnya warga Prancis secara berbondong-bondong ke Aljazair membuat semakin sedikit peluang bagi anak-anak pribumi untuk sekolah.
\end{abstract}

Kata kunci : Perkembangan Islam di Aljazair, penjajahan, pengaruh penjajahan.

Algeria is a part of the geography and economy of the Maghrib ethnic group which dominates Muslim areas from the West of Libya to the Atlantic Ocean. Muslims in Algeria can be divided into two parts, namely the Arabs and the Berber. The native population in Algeria is 
the Berber tribe. Algeria has been controlled several times by foreign nations. This is due to the condition of the population which is divided into various tribes. Before the arrival of France, the concept of education in Algeria gave subjects about the science of the Qur'an, interpretations, arithmetic and others. Then with a new policy made by France, learning methods were changed using French language and culture to make local schools closed. This condition makes the majority of children unable to continue their education, because those who are able to continue their education are only upper class families. Coupled with the arrival of French people in droves to Algeria, there are fewer opportunities for indigenous children to go to school.

Keywords: Development of Islam in Algeria, colonialism, influence of colonialism.

\section{A. Pendahuluan}

Aljazair merupakan salah satu wilayah dari kawasan Afrika Utara. Aljazair terletak di belahan Afrika Utara yang berbatasan dengan laut Mediterania. Karena letak geografis ini, Aljazair menjadi sumber daya alam yang sangat berlimpah dibanding dengan kawasan Afrika Utara yang lainnya.

Aljazair memiliki 48 provinsi yaitu, Adrar, Ain Defla, Ain Temouchent, Aljir, Annabah, Batnah, Bechar, Bejaia, Biskra, Blida, Bordj Bou Arreridja, Bouria, Boumerdes, Chelf, Constantine, Djelfa, El Bayadh, El Oued, El Tarf, Ghardaia, Gueima, Lilizi, Jizel, Khenchela, Laghout, Mascara, Medea, Mila, Mostaganem, M'Sila, Naama, Oran, Ouargia, Oum el Bouaghi, Kelizzane, Saida, Shatif, 
Sidi Bel Abbes, Skikda Souk Ahras, Tamanghasset, Tebbesa, Tiaret, Tindouf, Tipaza, Tissemsilf, Tizi Ouzou, Tlemcen.

Funisia dan Romawi merupakan bangsa asing yang pernah menguasai Aljazair. Funisia menguasai Aljazair pada tahun 1000 SM, sementara Romawi 146 SM. Setelah itu terjadi ekspansi oleh orang-orang Arab pada tahun 682, oleh Bani Umayyah dan berhasil menaklukkan Spanyol dengan bantuan suku Berber, setelah itu masuklah ajaran agama Islam ke Aljazair hingga saat ini.

Aljazair dikuasai oleh Dinasti al-Muwahhidun pada tahun 1152 di Maroko yang dipimpin oleh Abdul Mu'min bin Ali yang lahir di Tlemcen dari suku Zahata di Aljazair. Abdul Mu'min dalam kepemimpinannya memfokuskan kepada dua hal yaitu pertama menyebarluaskan tradisi ajaran Islam Muwahidiyyah ke seluruh kabilah di Maghrib dan menghapuskan seluruh ajaran yang telah disebarkan Murabbitun.

Pada tahun 1525 Aljazair dikuasai oleh Turki Utsmani melalui Khayruddin dan Aruj yang diberi julukan Barbarossa, dua saudara yang membebaskan Aljazair dari cengkaraman Spanyol. Perjuangan tersebut membuat Aljazair menjadi bagian dari Turki Utsmani dan dijadikan sebagai pusat bagi pemerintahan Aljazair. Sebelum datangnya Turki Utsmani negara ini dipimpin dari golongan kepala suku, para pemimpin lokal dan pemimpin tarekat. Pada tahun 1529 kepemimpinan dibagi 
lagi yaitu pemimpin dari Jennisary yang diberi gelar Bey dan Qadi yang memimpin kawasan masing-masing.

Seiring menurunnya pemerintahan Turki Utsmani memberikan dampak kepada Aljazair. Afrika Utara keluar dari kekuasaan Turki Utsmani termasuk Aljazair yang ikut serta keluar dari pemerintahan Turki Utsmani. Kemunduran Turki Utsmani merupakan bagian dari ketidakkondusifannya lagi dalam mengawasi daerah kekuasaan sehingga dengan mudah kawasan jajahan Turki Utsmani lepas dari kekuasaannya. Ekspansi Eropa juga menjadi salah satu penyebab kemunduran Turki Utsmani sehingga memberikan jalan kepada Prancis yang ingin menguasai Aljazair.

Turki Utsmani sempat melakukan penghadangan terhadap pasukan Eropa yang datang secara berbondong-bondong ke Afrika Utara khususnya Aljazair. Namun karena secara letak geografis lebih dekat dengan Eropa membuat Turki Utsmani tidak bisa mengamankan Afrika Utara secara menyeluruh. Pada abad ke $18 \mathrm{M}$, kerajaan Turki Utsmani semakin lemah sehingga dengan mudah Prancis memasuki Aljazair.

Tahun 1830 Prancis mengalami kemunduran akibat kekalahannya melawan Yunani sehingga Charles $X$ yang diutus oleh raja Prancis untuk melakukan penyerbuan terhadap Aljazair. Hal ini, merupakan salah satu cara untuk mengalihkan persoalan krisis ekonomi yang dialami Prancis atas kekalahannya melawan Yunani. Awalnya Prancis hanya ingin menguasai beberapa kota 
saja yang berada di pesisir, namun saat itu pemerintahan Turki Utsmani mengalami kemerosotan sehingga menjadi jalan bagi Prancis dalam menguasai Aljazair secara menyeluruh.

Pada tahun 1832 di Aljazair terjadi pemberontakan yang dipimpin oleh Abdul Qadir. Abdul Qadir mendeklarasikan diri sebagai pemimpin orang-orang Arab, bertanggung jawab untuk mengaplikasikan hukum Islam di Aljazair dan melawan aksi kolonial Prancis. Perjuangannya memperlihatkan seberapa besar loyalitasnya kepada masyarakat Aljazair. Tetapi upaya perlawanan tersebut membawa Aljazair secara menyeluruh di bawah kekuasaan Prancis. Akhirnya semua perlawanan bersenjata termasuk pasukan Abdul Qadir dan lainnya dihancurkan.

\section{B. Sejarah Masuknya Islam ke Aljazair}

Masuknya Islam ke wilayah Afrika Utara pada saat daerah tersebut berada di bawah kekuasaan kekaisaran Romawi. Awal dari penaklukan tersebut pada masa khalifah Umar bin Khattab. Kemudian setelah pergantian khalifah, penaklukan dilanjutkan oleh khalifah Utsman bin Affan Kejayaan Islam di Afrika Utara berlangsung pada masa kekuasaan Dinasti Umayyah. Setelah kemenangan yang diterima pasukan Arab, khalifah Umayyah mengutus Uqbah bin Nafi untuk menjadi gubernur di Afrika Utara. 
Pada tahun 666 M Uqbah bin Nafi menjadi gubernur dan berusaha untuk memulihkan kondisi masyarakat dan pasukan militer. Uqbah juga berhasil menebus beberapa wilayah yang masih menjadi tawanan Byzantium. ${ }^{1}$ Terjadinya pasang surut dalam penyebaran Islam di Afrika Utara yang disebabkan oleh pemberontakan bangsa Barbar atas penduduk Muslim dan muncul kekuatan Romawi yang mencoba kembali ingin menguasai Aljazair.

Proses pengislaman di Aljazair memiliki cara yang berbeda dalam masyarakat Berber. Penerimaan ajaran Islam memiliki tujuan untuk mengatur hubungan kesukuan dan memperluas perdagangan. Akibat dari penyebaran perdagangan dan adanya penyebaran agama Islam, sehingga menerima progresif terhadap simbol-simbol identitas masyarakat. ${ }^{2}$ Agama yang ada di Wlayah Aljazair merupakan Islam Sunni dan ada juga yang menggunakan Mazhab Maliki. Tapi penyebaran Islam dikalangan suku Berber tidaklah mudah karena banyak terjadi peperangan antara kaum Arab dan Berber.

Pada awal masa Islamisasi yang mengenal Islam lebih dulu hanya para kaum elit dan berkembang atas peranan para Maraboutisme. ${ }^{3}$ Maraboutisme yang ada di Aljazair berasal dari

\footnotetext{
1 Siti Maryam, Sejarah Peradaban Islam, h. 219

2 Ajid Thohir, Studi Kawasan Dunia Islam, (Jakarta:PT RajaGrafindo 2009) h. 296

${ }^{3}$ Maraboutisme atau Marabout adalah orang -orang yang dianggap suci, bijaksana dan memiliki kekuasaan lebih dalam suatu tempat. Marabout biasanya dari kalangan orang-orang yang taat dalam agamanya dan memberikan petunjuk keagamaan diantara masyarakat
} 
Andalusia di semenanjung Iberia yang membentuk organisasi dalam memperkuat gerakan Islam. Marabout sangat besar peranannya dalam bidang penyebaran agama, ilmu pengetahuan, bidang politik dan bidang sosial ekonomi. Seiring berjalannya waktu penduduk Aljazair mayoritasnya menganut agama Islam.

Pusat penyebaran Islam terjadi di Tahert atau Tiaret, atas jasa orang-orang Khawarij yang belum diketahui bagaimana kedatangannya di Afrika Utara. Orang-orang Berber yang menjadi mayoritas di Aljazir banyak yang memeluk agama Islam dan mencari tahu lebih dalam tentang Islam. ${ }^{4}$ Kejayaan Islam ditambah dengan penyebarluasaan Arabisasi yaitu bahasa Arab dijadikan bahasa Nasional di Aljazair. Melalui bahasa terjadi pernikahan anatara penduduk Berber dangan orang-orang Arab dan terbentuknya perkampungan orang Berber-Arab.

\section{Geografi dan Stuktur Masyarakat Aljazair}

Aljazair adalah salah satu bagian dari kawasan Afrika Utara. Aljazair sering disebut juga dengan Maghrib atau Berber. ${ }^{5}$

Negara Maghribi atau Maghrib merupakan sebutan bagi negara-negara yang berada dibagian utara benua Afrika, para pedaganglah yang pertama kali menyebut nama Maghrib. Maghrib meliputi bagian barat jika dilihat dari Jazirah Arab

\footnotetext{
4 Siti Maryam, Sejarah Kebudayaan Islam, h. 220

5 Samir Amin, The Maghreb In The Modern World-Algeria, Tunisia, Morocco, (Australis: Pinguin Books, 1970) h. 14
} 
termasuk Libya, Tunisia, Aljazair, Maroko, Mauritania dan Sahara Barat. Maghrib terbagi menjadi tiga bagian yaitu,

1. Maghrib al-Adnan yang artinya (Nearest Maghrib atau Maghrib Dekat), daerah yang terletak dibagian Afrika Utara. Istilah ini pertama kali diperkenalkan pada masa Dinasti Umayyah. Saat ini lebih dikenal dengan Negara Tunisia dan Libya.

2 Maghrib al-Aust yang artinya Barat Tengah hanya ada satu negara bagian yaitu Aljazair

3. Maghrib al-Agsa yang artinya Barat jauh negaranya meliputi Maroko, Mauritania dan Sahara Barat ${ }^{6}$

Berber merupakan suku asli yang keberadaanya sudah ada sejak masa Romawi. Penduduk Berber merupakan suku asli di kawasan Afrika Utara. Sejarah Yunani menyebutkan bahwa Berber adalah panggilan untuk orang-orang non- Yunani karena dianggap bukan bagian dari mereka. ${ }^{7}$

Berber juga sering disebut Barabir atau Barabira. Berber merupakan sekumpulan orang-orang yang tinggal dikawasan Afrika Utara yang kehidupannya berpindah-pindah. Mereka merupakan penduduk asli yang ada di Afrika Utara sebelum dan sesudah datangnya agama Islam. Penduduk Berber merupakan ciri dari penduduk asli yang berada di Aljazair.

\footnotetext{
${ }_{6}$ Samir Amin, The Maghreb In The Modern World-Algeria, Tunisia, Morocco, h.9-10

${ }^{7}$ Fabsin M. Fa'al, Sejarah Kekuasaan Islam, (Jakarta: CV Artha Rivera, Tth) h.97
} 
Bila ditelusuri ternyata keberadaan daerah yang sekarang disebut Aljazair mempunyai sejarah yang cukup panjang mulai dari 40 SM diperintah oleh bangsa Funisia, Romawi, Vandals, Byzantium (Nasrani), dan pada masa khalifah Utsman bin Affan sudah mulai melakukan perluasan wilayah ke Afrika Utara. Setelah terbunuhnya khalifah Utsman kekuasaan Islam di bawah khalifah Muawiyah bin Abu Sufyan yang mengutus Uqbah bin Nafi al Fihri sebagai pemimpin pasukan untuk menaklukan bangsa Romawi. ${ }^{8}$

Ketika terjadinya pergantian kekuasaan Aljazair pernah juga dikuasai oleh suku Vandals. ${ }^{9}$ Setelah dikuasai oleh Vandals, kemudian Aljazair diambil alih oleh Byzantium. Byzantium saat itu menguasai ibukota Afrika yaitu Chartago (Tunisia), dapat ditaklukkan oleh Bani Umayyah yang melakukan perluasan wilayah dan penyebaran ajaran agama Islam. Dalam ekspansi tersebut pasukan Arab dibantu oleh suku Berber Nomadic yang menganut agama Kristen. Pada akhirnya membuat suku tersebut ikut memeluk agama Islam. ${ }^{10}$

\footnotetext{
8 Siti Maryam, Sejarah Peradaban Islam,(Yogyakarta:LESFI, 2002) h.221

9 Awalnya suku Vandals bermigrasi ke wilayah Romawi, namun tidak bisa memasuki kawasan tersebut, akhirya bermukim di sekitar lembah Sungai Dnieper (Ukraina). Adapun suku Berber yang terkenal sebagai Vandal di Iberia datang dari Bayern (Jerman), kemudian nama Iberia diubah atas nama mereka menjadi Vandalusia. Agama yang dibawa orang-orang Vandals merupakan agama Kristen. Vandals juga disebut dengan Andalusia. Lihat: fabsin M.Fa'sal, Sejarah Kekuasaan Islam, h. 98

10 Siti Maryam, Sejarah Peradaban Islam, h. 222
} 
Proses peralihan kekuasaanpun terjadi setelah runtuhnya Bani Umayyah, Aljazair dikuasai oleh beberapa dinasti yang memilik kekuatan besar pada masa itu. Akhirnya menjadi bagian dari wilayah Dinasti Utsmani pada tahun 1525. Setelah itu pada abad 19 Aljazair dijajah oleh Prancis sehingga mengalami beberapa campuran bahasa.

Bahasa yang digunakan adalah Arab, Berber dan Prancis. Mata uang yang digunakan ialah mata uang Dinar Aljazair. Terdapat wilayah yang sangat subur di Aljazair yaitu, dibagian Utara karena terdapat pegunungan Atlas. Tempat ini digunakan untuk berladang oleh para penduduk yang tinggal dibagian tengah pegunungan. Letaknya stategis untuk para petani yang notabennya petani. ${ }^{11}$

Masyarakat Aljazair memiliki ciri yang berbeda karena dipisahkan ke dalam dua golongan yaitu masyarakat Eropa dan masyarakat Muslim. ${ }^{12}$ Antara keduanya memiliki hubungan yang erat, karena terjadinya pernikahan silang antara penduduk Aljazair dan Prancis saat masa jajahan. Namun setiap yang lahir langsung mendapatkan status kewarganegaraan Prancis. Sedangkan masyarakat muslim yang menganut ajaran Islam tetap

\footnotetext{
11 Trevor Mostyn, The Cambridge Encyclopedia of The Middle East And North Africa, (Camridge University Press, 1988) h.302

12 Adanya perbedaan masyarakat ini akibat adanya percampuran pernikahan yang terjadi sejak banyaknya orang-orang Eropa yang bermigrasi ke Aljazair sehingga menjadikan perbedaan masyrakat terjadi di Aljazair Lihat: Albert Hourani, The Modern Middle East, (London: I.B Touris, 2004) h. 178-179
} 
mendapatkan status sebagai warga Aljazair dan tetap menggunakan bahasa Arab.

\section{Masa Aljazair sebelum dikuasai oleh Turki Utsmani}

Aljazair memiliki sejarah panjang karena banyak dikuasai berbagai suku dan bangsa-bangsa asing, sehingga membuat Aljazair pernah tidak memiliki pemerintahan pusat dan identitas territorial. Namun setelah di kuasai berbagai bangsa, Aljazair mengalami perubahan dalam struktur sosialnya. ${ }^{13}$ Banyaknya pengelompokan suku-suku membuat Aljazair menjadi terbelah dan mudah dipengaruhi dari bangsa luar.

Bangsa asing yang diketahui pertama kali menguasai Aljazair adalah Funisia. ${ }^{14}$ Funisia menjadikan jalur perdagangan darat dengan menjual barang- barang ke kawasan Afrika Utara sebagai bentuk ekspansi bagi kekuasaannya. Cara menguasai daerah jajahannya bangsa ini menggunakan jalur perdagangan, kemudian setelah dimendapatkan keuntungan bangsa ini menguasai daerah yang didatanginya.

\footnotetext{
${ }^{13}$ Ira M Lapidus, Sejarah Sosial Umat Islam, (Jakarta: PT RajaGrafindo,1999) Jilid I,II h 611.

14 Funisia atau Phoenicia adalah orang-orang yang hidup di wilayah pantai Timur dari Mediterania (Libanon). Orang-orang Funisia berasal dari Libanon yang gemar berlayar dan melakukan perdagangan di jalur laut yang disinggahinya sehingga menjadikan Funisia memiliki perekonomian makmur. Lihat: Siti Maryam, Sejarah Peradaban Islam Dari Masa Klasik Hingga Modern, h.226
} 
Setelah itu kekuasaannya berpindah ke bangsa Romawi. ${ }^{15}$ Bangsa Romawi berkuasa 146-439 SM yang dipimpin oleh pasukan orang-orang Kristen, sehingga banyak penduduk Berber yang menganut ajaran Kristen pada saat itu para penguasanya memiliki ajaran yang sama. Kekuasaanpun jatuh ke tangan suku Vandal setelah peperangan terjadi. Akhirnya pada tahun 439-534 M, Aljazair dikuasai oleh suku Vandals dan Byzantium pada tahun 534-647 M. ${ }^{16}$ Peralihan

kekuasaan terjadi, sehingga sampai kepada masa kekuasaan Islam datang dan mulai menguasai kawasan Afrika Utara.

Pada tahun $670 \mathrm{M}$ penaklukkan Arab terjadi terhadap kawasan Maghrib, penyebaran ajaran Islam yang dilakukan pada masa dinasti Umayyah. Pemerintahan diatur sesuai dengan syariat Islam dan banyak pula penduduk Berber yang masuk Islam. Setelah itu ada beberapa dinasti yang pernah memimpin Aljazair.

Dinasti dalam bahasa arab adalah dawlah yang artinya "peredaran dan giliran". Menurut Franz Rozental dinasti merupakan sebuah teori yang terjadinya pergantian penguasaan yang dikutip dalam karya al-Kindi dalam Risalah fi Mulk al-Arab. Dalam beberapa buku yang penulis baca beberapa penjelasan di

\footnotetext{
${ }^{15}$ Michael I. Levy, The History Of Northen Africa,(New York: Britannica Educational Publishing,2010) h.7

16 Byzantium merupakan sebuah kota yang berada di Yunani yang menjadi kota kekaisaran tahun 196 dan pada masa Turki Utsmani di rubah menjadi nama Instanbul yang menjadi Ibu kota Turki.
}

92 AT-TUROTS: Jurnal Pendidikan Islam 
bawah ini merupakan urutan dinasti-dinasti yang pertama kali menguasai Aljazair.

Dinasti Rustamiyah yang saat itu dipimpin oleh Abdurrahman ibn Rustam telah berhasil menguasai Aljazair. Keberadaan dinasti ini merupakan bentuk dari protes terhadap dominasi Arab yang sunni. Dinasti Rustamiyah berakhir dengan jatuhnya Tahart Dinasti Fatimiyah tahun 777-909 M. ${ }^{17}$ Taharat atau Tairet adalah tempat penyebaran Islam untuk pertama kalinya di Aljazair. Tahart di masa Rustamiyah mengalami kemakmuran dan merupakan pusat ilmu pengetahuan agama yang tinggi khususnya aliran Khawarij untuk seluruh Afrika Utara.

Dinasti Aghlabiyah merupakan salah satu dinasti yang pernah berkuasa di Aljazair setelah Dinasti Rustam. Dinasti Aghlabiyah berdiri di Aljazair tahun 800- 909 M, yang didirikan oleh Ibrahim Ibn al-Aglab. Tujuan dinasti ini untuk menghapuskan kekuasaan Rustamiyah yang beraliran Khawarij. Kekuasaan Dinasti Aghlabiyah meluas sampai ke timur Aljazair sehingga ajaran Islam dengan mudah menyebar luas. ${ }^{18}$ Tetapi setelah kemundurannya para pemimpin dari dinasti Aghlabiyah di usir dari Afrika Utara dan digantikan oleh dinasti selanjutnya.

Dinasti Fatimiyyah didirikan oleh Ubaidillah al-Mahdi tahun 1171 di Afrika Utara kemudian menyebar ke Mesir dan

17 Ali Mufrodi, Islam Di Kawasan Kebudayaan Arab, Ciputat, Logos, 1997 h.20

18 Syamsul Bakri, Peta sejarah peradaban Islam, Yogyakarta: Fajar Media Press, 2011 $\mathrm{h}$ 
Syria. Meskipun kekuasaannya berada di Mesir, dinasti ini pengaruhnya sampai ke Aljazair. Dinasti Fatimiyyah merupakan dinasti yang beraliran Syi'ah Ismailliyah. Dinasti ini di nisbatkan nasabhnya kepada keturunan Nabi yaitu ke nasab Fatimah binti Rasulullah, sehingga mereka menamai dinastinya dengan nama Dinasti Fatimiyyah.

Selanjutnya yang menguasai Aljazair adalah Dinasti Hammadiyah yang berdiri 972-1152 M berkuasa di Aljazair bagian Timur yang terletak di kota Qairawan. ${ }^{19}$ Pada tahun yang bersamaan muncul pula Dinasti Ziriyah yang terdiri dari suku Berber, suku ini ikut membantu pada masa Fattimiyyah dalam memperluas kekuasaannya ke daerah Mesir, sehingga terpecah kedalam dua bagian daerah yaitu daerah barat yang diberikan kepada Hammadiyyah dan bagian Timur tetap dikuasai oleh suku Berber Ziriyah. Namun setelah terjadinya peperangan kedua dinasti ini jatuh kepada kekuasaan Dinasti Fatimiyyah.

Dinasti Al Murabittun awalnya berkuasa di Maroko dan Spanyol dinasti ini didirikan oleh Abu Bakar al Lamtuni yang berasal dari suku Sanhajah. Dalam misinya menyebarkan ajaran Islam dari Maroko hingga ke Aljazair. Pada masa Dinasti AlMurabittun proses penyebaran dan Islamisasi sangatlah cepat meluas sampai banyaknya penduduk Afrika bagian Barat yang masuk Islam. ${ }^{20}$

19 Ira M. Lapidus, Sejarah Sosial Ummat Islam Jilid I-II h. 564

20 Samsul Munir Amin, Sejarah Peradaban Islam, ( Jakarta: AMZAH, 2013) 
Dinasti al-Muwahhidun pada tahun 1152 yang dipimpin oleh Abdul Mu'min bin Ali yang lahir di Tlemcen suku Zahata di Aljazair. Abdul Mu'min dalam kepemimpinannya memfokuskan kepada dua hal yaitu pertama menyebarluaskan Muwahhidiyah ke seluruh kabilah di Maghrib dan menghapuskan seluruh ajaran yang telah diberikan Murabbitun. Dinasti Muwahhidun adalah sebuah dinasti Islam yang pernah berjaya di kawasan Afrika Utara dan Spanyol kurang lebih satu abad. ${ }^{21}$

Awal berdirinya Dinasti Hafsiyah di Tunisia pada tahun 1547 kekuasaannya meluas hingga sampai ke wilayah Aljazair bagian Timur. Dinasti ini didirikan oleh Syaikh Abu Hafs Umar. Dinasti Mariniyah 1549 M yang terdiri dari penduduk Berber yang nomad salah satu dinasti yang pernah singgah di Aljazair. Namun kekuasaan ini tak terlalu lama karena kekalahan saat ingin menundukkan Spanyol kemudian dinasti ini dihancurkan.

Setelah dinasti Hafisyyah mengalami kehancuran yang menguasai Aljazair yaitu dinasti Mariniyah. Dinasti ini terdiri dari kelompok yang didominasi dari sebuah koalisi penduduk Berber Zenata yang menggulingkan al-Muwahiddun dan dinasti ini pula yang menaklukkan Maroko. Meski di Maroko, kekuasaan dinasti ini sampai pula ke wilayah Aljazair. ${ }^{22}$ Dinasti ini membangun pemerintahannya di Fez serta mendirikan sebuah istana dan administrasi yang didukung oleh koalisi suku-suku

21 Samsul Munir Amin, Sejarah Peradaban Islam, h 270

22 Naylor, Phillip C, North Africa A (History from Antiquity to the Present), (USA: University of Texas Press, 2009) h.95 
yaitu dari suku Bani Marin, Bani Ma'qil dan beberapa suku Berber Zenata yang berada di Aljazair. Aljazair belum memiliki pemerintahan pusat karena, pergantian dinasti yang menguasainya dan kebiasaan penduduk Aljazair yang nomad. Pengaruh dari dinasti yang pernah menaklukkan Aljazair membuat banyaknya penduduk yang memeluk Agama Islam. Setelah itu Aljazair dikuasai dinasti Utsmani yang menjadikan negara ini memiliki kepemimpinan pusat dan adanya sistem pemerintahan yang diatur oleh kekuasaan Utsmani.

\section{E. Masa Aljazair setelah dikuasai oleh Turki Utsmani}

Turki Utsmani merupakan salah satu dinasti yang berkuasa di wilayah Anatolia di Turki. Dinasti ini berkuasa dari tahun 1280-1992 M. Nama Utsmani diambil dari pendirinya yaitu Utsman bin Ertughrul. Dinasti Utsmani terdiri dari suku Qayigh Oghuz.

Dalam buku Siti Maryam Sejarah Peradaban Islam, ${ }^{23}$ suku Oghuz dipimpin oleh Sulaiman Syah. Sulaiman Syah mengajak semua anggotanya yaitu suku Oghuz untuk menghindar dari serbuan bangsa Mongol yang saat itu sedang menyerang dunia Islam. Sulaiman dan anggotanya melarikan diri ke arah barat dan meminta perlindungan Jalaludin dan menyuruh pergi ke Asia

23 Siti Maryam dkk, Sejarah Peradaban Islam, (Yogyakarta: LESFI, 2002) h 151-152 
Kecil. Suku Oghuz ${ }^{24}$ memang terkenal dengan sebutan orangorang nomad, karena seringnya berpindah-pindah tempat. Syam merupakan salah satu tempat yang pernah dijadikan tempat untuk menghindari dari serangan Mongol, Ketika dalam perjalanan menuju Syam, Sulaiman Syah dan rombongannya hanyut di sungai Eufrat dan terbagi menjadi dua kelompok.

Kelompok pertama memutuskan untuk kembali ke negri asalnya. Dan kelompok kedua terus melanjutkan perjalanannya menuju Asia Kecil. Sulaiman Sah meninggal dalam peristiwa hanyutnya di sungan Eufrat. Yang digantikkan oleh anaknya Ertugrul. Ertogrul membantu dinasti Saljuk dalam peperangan melawan Bizantium sehingga mengalami kemenangan dalam pertempuran tersebut. Setelah Ertugrul meninggal tongkat estafet diambil alih oleh anaknya yang bernama Utsman sekaligus pendiri pertama dinasti Utsmani. Sejak itulah Utsman bin Ertugrul dengan resmi dikenal dengan sebutan Utsmani. ${ }^{25}$

Turki Utsmani mengalami ekspansi besar-besaran dalam memperluas wilayahnya. Pada periode pertama Utsmani berhasil menaklukkan negeri-negri non muslim. ${ }^{26}$ Beberapa wilayah yang dapat ditaklukkan para sultan di periode awal adalah Ankara, Izmir atau Asia Kecil dan Turki. Turki Utsmani memiliki pasukan

\footnotetext{
${ }^{24}$ Suku Oghuz dalam literature Indonesia di sebut dengan suku Koyi Lihat: Siti Maryam dkk, Sejarah Peradaban Islam, hlm.151yang dikutip dari buku C.E. Bosworth, Dinasti-dinasti Islam, 1980 hlm.163

25 Syamsul Bakri, Peta sejarah peradaban Islam, (Yogyakarta: Fajar Media Press, 2011) h.135

${ }^{26}$ Abdullah, Taufik, ed. Ensiklopedi Tematis Dunia Islam: Khilafah, h.87
} 
militer yang sangat kuat seperti memiliki senjata yang sangat canggih sehingga dapat memberikan dorongan terhadap keberanian dalam menaklukkan wilayah-wilayah tersebut.

Pada periode kedua ekspansi masih terus berlanjut sehingga ditaklukkannya kota-kota penting pada masa itu yaitu kota Constantinopel dan diganti namanya menjadi Istambul. Perpindahan ibu kota berlanjut dan pada akhirnya Istambul menjadi ibukota tetap hingga saat ini.

Pada periode ketiga dan keempat perselisihan mulai terjadi di dalam pemerintahan salah satunya munculnya kekuatan Jennisari menimbulkan perpecahan yang terjadi sehingga pada masa sultan Muhamad II ia mencabut jabatan tokoh-tokoh penting yang ada di Turki dan seluruh keluarga Utsmani yang terlibat terhadap pemerintahan Turki Utsmani.

Hal tersebut mulai memberikan kebebasan kepada orangorang Kristen yang berada di Turki Utsmani. Penduduk Kristen dapat hidup leluasa di bawah kekuasaan Turki Utsmani dan dapat menikmati hasil bumi. Sepanjang perjalannya Utsmani digantikan oleh banyak pemimpin. Turki Utsmani merupakan salah satu di antara dinasti yang menjadi kebangkitan peradaban Islam. Pada masa ini merupakan periode kejayaan dalam sejarah peradaban Islam muncul kembali setelah runtuhnya dinasti Abbasiyah.. Wilayah Turki Utsmani pada awalnya sangatlah kecil, namun pada saat di pimpin oleh Sultan Urkhan untuk pertama kalinya tentara Utsmani memasuki Eropa. 
Kekuatan militer yang sangat kuat sehingga berhasil membentuk tiga pasukan militer. Pertama, pasukan Sipahi yaitu tentara resmi yang diberikan gajih oleh negara di setiap bulannya. Kedua, pasukan Hajeb pasukan ini mendapat bayaran atau gaji juga tetapi ketika setelah terjadinya perang dan mendapat harta rampasan. Ketiga, pasukan Jenisari yang terdiri dari orang-orang Kristen yang telah diislamkan. ${ }^{27}$

Seiring berjalannya waktu perluasan wilayah yang dilakukan Turki Utsmani dengan pasukan militer yang sangat kuat bermaksud untuk menaklukan daerah Laut Tengah saat itu yang menjadi Sultan yaitu Sulaiman Al-Qanuni !520-1566 dibawah kepemimpinan militer Khairuddin Barbarosa mengambil alih Aljazair pada tahun 1529. Aljazairpun dengan resmi telah menjadi provinsi Kesultanan Utsmani yang berkuasa selama empat abad. Aljazair tumbuh pada masa penaklukan Turki, otonomi administratif yang diperluas dari Istanbul dan di integrasi kaum penguasa Turki dengan kepemimpinan Berber dan Arab lokal. ${ }^{28}$

Tidak hanya itu Barbarosa sukses menaklukkan Aljazair dengan bantuan pasukan Jennisari sehingga menjadi kekuatan besar dalam menaklukkan Aljazair. Ketika sudah jatuh ke tangan Utsmani terbentuklah rezim Afrika Utara di bawah kekuasaan Usmani yang dimpimpin oleh Sultan Sulaiman Al Qanuni 1520-

27 Fabsin M. Fa'al, Sejarah Kekuasaan Islam, hlm.244

28 John L. Esposito, Dunia Islam Modern, (Bandung: Mizan, 2001) h. 1066 
1566 M. Keadaan Utsmani mengalami kemajuan baik dalam ekonomi atau perluasaan wilayah.

Barbarossa bukanlah nama melainkan julukan untuk dua orang kakak beradik. Dalam bahasa Berber Barbarossa berarti Janggut dan Merah yang digabungkan menjadi janggut merah. Nama tersebut diberikan oleh para pelaut Eropa kepada kakak beradik Khairuddin dan Aruj dari Turki. Khairuddin Barbarossa berasal dari Lesbos ${ }^{29}$ dua orang ini merupakan pejuang jihad yang melawan pasukan portugis dan Spanyol.

Kemajuan ekonomi dalam bidang pajak dan militer yang sangat ditakuti (Jennisari) perdagangan memiliki peran sangat penting dalam hubungan antara Timur dan Barat. Semua itu membuat kawasan yang berada dibawah kendali Utsmani mengalami kestabilan dalam bidang perekonomian dan tingkat keamanan yang sangat tinggi. Aljazair memiliki sumber daya alam yang sangat banyak seperti Minyak Zaitun, buah-buahan dan memiliki hasil laut yang sangat melimpah. ${ }^{30}$ Inilah yang membuat Aljazair dalam bidang ekonomi mengalami kemajuan dan penduduknyapun saat itu menjadi makmur.

Pada tahun 1587 resmi memiliki gubernur atau yang sering disebut Berleybey yang di tunjuk oleh pasukan Jennisari. ${ }^{31}$ Jatuhnya Aljazair ke tangan Utsmani sebagai bentuk dari perluasan kekuasaan yang di alami Utsmani. Aktivitas

\footnotetext{
${ }^{29}$ Lesbos merupakan nama sebuah pulau yang berada di Turki.

30 Ajid Thohir, Studi Kawasan Dunia Islam, (Jakarta:PT RajaGrafindo, 2009) h.98

31 Ira M Lapidus, Sejarah Sosial Umat Islam, (Jakarta:PT RajaGrafindo,1999) h. 611
} 
perekonomian di Aljazair dikendalikan oleh Utsmani salah satunya jalur perdagangan yang dikuasai Utsmani.

Kestabilan dalam bidang ekonomi dan militer sangat tinggi sehingga berdampak baik bagi Aljazair. Sebelum jatuh pada kekuasaan Utsmani, Aljazair tidak pernah memiliki pusat pemerintahan dan tidak memiliki identitas sendiri.

Kedatangan Utsmani merubah pola pemerintahan sehingga Aljazair memiliki identitas dalam pemerintahnnya. Para penguasa sebelumnya lebih mengutamakan patuh terhadap pemimpin dan solidaritas kesukuan. Setelah Aljazair dikuasai Utsmani dan diambil alih oleh pasukan Jennisary lebih diarahkan lagi terhadap kepedulian cinta tanah air dan menekankan militer dan hubungan antara sultan di Istanbul berjalan dengan baik. Aljazair dipimpin oleh Bey, Qa'di dan Dey.

Qadi dan Bey ${ }^{32}$ pada masa Utsmani ditunjuk dari kalangan agamis yang taat kepada syariat Islam dan dilihat juga dari keturunannya sehingga bisa memberikan pengaruh besar terhadap masyarakat lain dalam mempererat hubungan dengan Turki. Dua jabatan tersebut diberi mandat untuk mengatur masalah perpajakan dan memfokuskan organisasi militer.

\footnotetext{
32 Bey sudah ada sejak tahun 1587 saat Barbarossa menaklukan Aljazair,. Aljazair yang kala itu dipimpin oleh Berlebey atau Bey yang artinya Kepala Proponsial yang di tunjuk langsung oleh Sultan Utsmani yang mendapat dukungan dari pasukan Jennisari. Adanya kekuatan Bey ini di bentuk sesuai komando oleh pimpinan tentara Jennisari. Sedangkan Qadi ialah kepala Suku yang memimpin di Aljazair dan mengatur para pemuka-pemuka sukudan menyelesaikan perselisihan dan pemungutan pajak. Lihat: Ira M. Lapidus, Sejarah Sosial Ummat Islam, jil I-II h. 611
} 
Dey atau kepala negara yang diangkat oleh Sultan di Istanbul, yang memerintah dengan stabil, menegakkan hukum syariat, dan memperlakukan Aljazair sebagai wilayah otonom. Aljazair di bawah Turki Utsmaniah adalah dar al-jihad melawan musuh-musuh dari Spanyol dan Perancis. Legitimasi Imperium Utsmaniah dalam hal ini adalah sebagai pelindung ummah. Tugas Dey memimpin khususnya tiga wilayah yaitu Titteri, Constantine dan Mascara. Serta mengatur kota Aljazair dan mata pencariannya yaitu pertanian.

Kawasan Afrika Utara pada tahun 1580 tetap menjadi perebutan oleh Spanyol dan Portugal. Kedua negara tersebut berambisi menguasai Afrika Utara khususnya daerah pantai Maroko dan Aljazair, namun sultan Utsmani memfokuskan untuk melindungi Afrika Utara khususnya Aljazair. Karena itu diadakan perjanjian untuk melindungi warga Afrika Utara. Sehingga timbulah rasa aman yang dirasakan masyarakat. Keberhasilan Utsmani dipengaruhi oleh visi dinasti yaitu sebagai pelaku ekspansi Islam untuk membebaskan wilayah- wilayah baru.

Pada masa itu Utsmani lebih membangun kekuatan secara struktural dari segi politik, militer dan ekonomi untuk memajukan Aljazair, tetapi dalam bidang kebudayaan hanya bahasa Arab yang dijadikan bahasa resmi yang digunakan di semua kawasan Afrika Utara termasuk Aljazair sampai saat ini.

Ajaran agama Islam yang melekat di Aljazair merupakan salah satu pengaruh yang diberikan Utsmani terhadap Aljazair. 
Sehingga suku-suku yang dominanya Berber mereka semua ikut masuk agama Islam. Dalam bidang pertahananpun, masyarakat Aljazair dilatih khusus sehingga bisa menjaga bagian pesisir Aljazair yang selalu dijadikan jalan untuk bangsa asing menduduki Aljazair.

Wilayah adminisrasi dikendalikan langsung oleh kepala suku dan penduduk yang dipilih untuk menangani ketidakadilan oleh berbagai suku di Aljazair. Terbentuknya struktur kesukuan dengan menggabungkan kekuataan dari suku-suku kecil sehingga timbullah suara untuk bisa mengangkat pimpinan lokal. Hal ini membuat masyarakat bisa disatukan oleh kebijakan pusat yang di tentukan Utsmani. ${ }^{33}$

Pengaruh kepala suku dan pemimpin keagamaan yaitu Sufi sangatlah besar karena berperan dalam membangun persatuan penduduk Aljazair dan bisa membangun sejumlah pemakaman dan masjid-masjid yang dihasilkan dari pajak.

Turki Utsmani merupakan salah satu dari tiga kerajaan besar yang pernah berjaya hingga awal abad kesembilan belas. Keberadaan Utsmani sangatlah penting dalam sejarah dunia Islam yang membawa kemajuan dan kejayaan Islam di dunia. Turki Utsmani yang berkuasa tahun 1258-1926 membawa perubahan bagi sistem pemerintahan dan disentralisasi bagi pemerintahan Aljazair.

33 Michael I, Levy, The History of North Afrika, (New York: Britannica Educational Publishing, 2010) h.55-57 
Dalam perjalanan sejarahnya Turki Utsmani mengalami lima periode kepemimpinan. Kemunduran mulai terasa setelah wafatnya Sultan Sulaiman al Qanuni yang digantikan oleh Sultan Salim II 1566. ${ }^{34}$ Terjadinya berbagai peperangan yang berujung dengan kekalahan sehingga membuat kerugian bagi pihak Utsmani.

Inilah masa dimana kemunduran Utsmani mulai terjadi, sistem pemerintahanpun mulai goyah karena banyaknya para pemimpin-pemimpin Utsmani yang kurang memperhatikan daerah kekuasaannya. Tetapi dengan pergantian kepemimpinan oleh khilafah selanjutnya bisa menyeimbangkan kemunduran dan membuat keadaan menjadi stabil kembali. Beberapa faktor yang membuat Utsmani sukses dalam melakukan ekspansinya yaitu:

Pertama kemampuan dalam menyusun strategi sehingga bisa menaklukkan beberapa wilayah penting. Kekuatan Jennisari merupakan pertahanan militer yang sangat terkenal pada masa Utsmani. Pasukan Jennisari ialah pasukan militer utaman yang dimiliki Turki Utsmani yang terdiri dari dua bangsa yang telah masuk Islam yaitu bangsa Georgia dan Armenia. Kota penting yang ditaklukan pada masa ekspansi Utsmani adalah kota Constantinopel sebagai ibukota kerajaan Romawi Timur. ${ }^{35}$

\footnotetext{
34 Badri Yatim, Sejarah Peradaban Islam, (Jakarta: PT RajaGrafindo Persada, 2008) h. 165

35 Siti Maryam dkk, Sejarah Kebudayaan Islam Dari Masa Klasik Hingga Modern, (Yogyakarta: LESFI, 2004) h.131
} 
Kedua keinginan jihad yang sangat tinggi dan gaya hidup yang sederhana. Taatnya para muslim terhadap agama membuat kemudahan dalam menjalankan ekspansi terhadap wilayah yang dikuasai oleh Romawi, dengan itikad berjihad membuat semangat para pasukan dalam menaklukan wilayah.

Ketiga letak Istanbul yang sangat strategis sehingga memudahkan perluasan kekuasaan dan kondisi dinasti-dinasti disekitarnya yang sedang kacau. Setelah ditaklukannya Constantinopel dan diubah namanya menjadi Istanbul memberi jalan kemudahan bagi Turki Utsmani dalam meneruskan jihadnya karena, Istanbul merupakan pusat kebudayaan dan peradaban. Terdapat dua penghubung antara benua Eropa dan Asia sehingga menambah keindahan kota tersebut.

Selama menguasai Aljazair, Utsmani memberikan hak kepada masyarakat Aljazair dalam pembentukan politik. Serta membantu membuat peraturan yang sesuai dengan keberagaman suku di Aljazair. Seiring berjalannya waktu dengan kemunduran Utsmani membawa Aljazair pada kekuasaan kolonial Prancis yang berkuasa selama 132 tahun

Melemahnya kekuasaan Utsmani dikarenakan terjadinya perubahan situasi politik yang berdampak pada perubahan ekonomi dan bangkitnya imperialis bangsa Eropa. ${ }^{36}$ Banyak yang mempengaruhi Turki Utsmani hal ini, membuat terjadinya

36 Ira M. Lapidus, Sejarah Sosial Ummat Islam Jilid 1-2, (Jakarta: PT Raja Grafindo Persada1999) h. 415 
kemunduran. Melemahnya Utsmani karena sebagian para pemimpin tidak siap sepenuhnya dalam menguasai Utsmani dan semua daerah kekuasannya. Wilayah-wilayah yang cukup luas membuat sulit untuk diawasi. Awal dari sinilah proses awal kemunduran Turki Utsmani terjadi dan membawa Aljazair dalam kekuasaan kolonial Prancis.

Selama hampir dua abad sejak terjadinya ekspansi Prancis, dan membuat Utsmani mengalami dampak yang sangat besar baik dalam bidang ekonomi maupun politik. Ekspansi perdagangan Eropa yang melewati lautan di daerah Utsmani membuat pemerintah kehilangan kontrol atas beberapa sumber pendapatan pajak dari beberapa provinsi sehingga ekonomi masyarakat mengalami penurunan. Kelemahan militer juga menyebabkan krisis keuangan yang permanen. ${ }^{37}$

Sedangkan kekuatan militer Jennisari yang sangat terkenal pada masanya menghilang seiring dengan terjadinya demoralisasi, Utsmani menghentikan ekspansinya ke berbagai wilayah sehingga melemahnya loyalitas tentara Jennisari dan tidak lagi mendapatkan harta rampasan. Hal ini yang memberikan peluang bagi daerah yang dikuasai oleh Utsmani untuk keluar dari wilayah kekuasaan Utsmani. Karena sudah tidak ada lagi peperangan dan mendapatkan harta rampasan

37 Erik J. Zurcher, Sejarah Modern Turki,(Jakarta: PT Gramedia Pustaka Utama, 2003) h.11 
sehingga membuat Utsmani tidak melakukan lagi perluasan untuk kekuasaannya.

Terjadinya pembaharuan yang dicanangkan oleh Sultan Mahmud II yang menggantikan pasukan Jennisari dengan corps atau pasukan baru. Pasukan Jennisari yang tidak menginginkan pembaharuan mengakibatkan terjadinya bentrokan antara Sultan dengan perwira-perwira yang tidak menyetujui adanya corps baru dalam bidang militer. Hal ini, membuat terjadinya pertumpahan darah dan hilangnya pasukan Jennisari dari Utsmani. ${ }^{38}$

Pemberontakan yang dilakukan Jennisari membuat pemerintahan pusat tidak lagi memiliki kendali atas propinsipropinsinya karena, yang memiliki wewenang adalah para panglima perang. Kekuasaan yang dimiliki para panglima ini, meliputi daerah Balkan, Anatolia dan Mesir.

Pada 16 Juni 1826 dikeluarkannya keputusan untuk membubarkan pasukan Jennisari. Penghapusan Jennisari dengan menghancurkan barak-barak dan semua pemakamannya di bongkar sehingga tidak lagi terlihat persatuan dari pasukan Jennisari. ${ }^{39}$ Kesatuan militer Jennisari selama lima abad bisa berakhir karena perubahan sistem yang dulunya lebih kearah peperangan berubah ke pembaharuan. Pasukan Jennisari yang

\footnotetext{
38 Harun Nasution, Pembaharuan Dalam Islam , (Jakarta: PT Bulan Bintang, 2014) h. 83-84

39 John Freely, Istanbul Kota Kekaisaran,, (Jakarta: Pustaka Alvabet, 2012) h. 335
} 
selama lima abad berkiprah dalam kekuasaan Utsmani sampai dibubarkan karena adanya perubahan sistem pemerintahan dan terjadinya pengaruh dari bangsa asing.

Terjadinya pembaharuan dalam pemerintahan membuat wilayah kekuasaan tidak lagi menjadi perhatian dan menjadi kesempatan bagi Eropa untuk merebut wilayah-wilayah kekuasaan Utsmani. Hal ini mengantarkan wilayah Afrika Utara yaitu Aljazair menjadi sasaran dalam perluasan kekuasan Eropa. Setelah Afrika Utara bebas dari kekuasaan Utsmani bangsa Eropa mulai berdatangan ke pesisir Aljazair, dengan pertahanan perbatasan yang lemah memudahkan pasukan militer Eropa masuk ke Aljazair.

\section{F. Kesimpulan}

Berdasarkan hasil penelitian yang telah dilakukan melalui sumber tertulis, maka hasil kesimpulan yang didapat yaitu: Aljazair sebelum datangnya Prancis merupakan wilayah yang penduduknya bersuku-suku, hidup secara nomad dan memiliki mata pencarian dengan bertani. Tanah yang subur mempermudah dalam bercocok tanam. Aljazair juga pernah dikuasai bangsa asing dan setelah terjadinya ekspansi Arab. Ekspansi Arab terjadi pada masa Khilafah Rasyidin masa Utsman bin Affan. Sampai masa berdirinya khilafah-khilafah 
Islam. Hal ini, merupakan awal terjadinya penyebaran agama Islam dan Turki Utsmani adalah kekhalifahan Islam yang terakhir menguasai Aljazair.

Dengan berakhirnya ekspansi Arab di kawasan Afrika Utara memulai debut baru kepada daerah-daerah yang lepas dari kekuasaan Utsmani. Setelah lepas dari kekuasaan Utsmani, Aljazair tidak memiliki pemerintahan tetap. Dengan mangandalkan sistem pemerintahan lokal berlajan. Keadaan ini dimanfaatkan Prancis dalam mencoba untuk menjajah Aljazair. Keadaan penduduk semakin memburuk ketika beberapa kebijakan ditetapkan Prancis. Kemiskinan dan kebodohan semakin merajalela ketika mata pencarian dan pendidikan yang dibatasi sehingga tak banyak anak-anak yang tidak dapat mengenyam pendidikan dan orang-orang dewasa yang tak memiliki pekerjaan.

Di Aljazair, universitas yang berstatus universitas Islam yang menyediakan khusus fakultas-fakultas Islam hanya satu, yaitu Universitas Amer Abdel Kader. Sementara universitas Aljazair (Universite d'Alger), meskipun bukan universitas Islam, tapi membuka beberapa fakultas studi Islam. Selebihnya hanya sebagai institute atau sekolah tinggi Islam yang menyediakan beberapa jurusan keislaman. Selain itu, di universitas lain tidak menyediakan studi Islam. 


\section{DAFTAR PUSTAKA}

Abdullah, Taufik, Ensiklopedi Tematis Dunia Islam: Khilafah, Jakarta: PT Ichtiar Baru Van Hoeve,Tth

Amin, Samir, The Maghrib In The Modern World Algeria-TunisiaMorocco, Australia: Pinguins Book, 1970.

Amin, Samsul Munir ,Sejarah Peradaban Islam, Jakarta: Amzah, 2013.

Bakri, Syamsul, Peta sejarah peradaban Islam, Yogyakarta: Fajar Media Press, 2011.

Esposito, John L, Ensiklopedi Oxford Dunia Islam Modern, Bandung: Mizan 2001,

Fa'al, Fabsin M, Sejarah Kekuasaan Islam, Jakarta: CV Artha Rivera, Tth.

Freely, John, Istanbul Kota Kekaisaran, Jakarta: Pustaka Alvabet, 2012.

Lapidus, Ira M, Sejarah Sosial Umat Islam, Jakarta: PT Raja Grafindo,1999.

Levy, Michael I, The History of North Afrika, New York: Britannica Educational Publishing, 2010.

Maryam, Siti dkk, Sejarah Kebudayaan Islam Dari Masa Klasik Hingga Modern, Yogyakarta: LESFI, 2004.

Maryam, Siti, Sejarah Peradaban Islam, Yogyakarta:LESFI, 2002.

Mostyn,Trevor,The Cambridge Encyclopedia of The Middle East And North Africa, Newyork: Camridge University Press,1988

Mufrodi, Ali, Islam Di Kawasan Kebudayaan Arab, Ciputat: Logos, 1997.

Nasution, Harun, Pembaharuan Dalam Islam , Jakarta: PT Bulan Bintang, 2014. 
Phillip, Naylor C, North Africa A (History from Antiquity to the Present), USA: University of Texas Press, 2009.

Thohir, Ajid, Studi Kawasan Dunia Islam, Jakarta:PT Raja Grafindo, 2009.

Yatim, Badri, Sejarah Peradaban Islam, Jakarta: PT Raja Grafindo Persada, 2008.

Zurcher, Erik J., Sejarah Modern Turki, Jakarta: PT Gramedia Pustaka Utama, 2003 